\title{
Extraction of Pectin From Apple Pomace
}

\author{
Maria Helene Canteri-Schemin ${ }^{1}$, Heloísa Cristina Ramos Fertonani ${ }^{2}$, Nina Waszczynskyj ${ }^{3}$ \\ and Gilvan Wosiacki ${ }^{2 *}$ \\ ${ }^{I}$ Centro Federal de Educação Tecnológica do Paraná; Unidade de Ponta Grossa; Coordenação de Alimentos; \\ Ponta Grossa - PR - Brazil; ${ }^{2}$ Universidade Estadual de Ponta Grossa; Departamento de Engenharia de Alimentos; \\ Av. Carlos Cavalcanti, 4748; 84030-900; Ponta Grossa - PR - Brazil; ${ }^{3}$ Universidade Federal do Paraná; \\ Departamento de Engenharia Química; Pós-Graduação em Tecnologia de Alimentos; Curitiba - PR - Brazil.
}

\begin{abstract}
As apple-processing units are now in expansion in Brazil, industrial by-products like pomace play an important role in pectin manufacture. The objective of this article was to determine a pratical follow-up to the extraction of pectin from apple pomace and to characterize it in a laboratory, on a small scale, aiming at establishing the optimum conditions for acid extraction. The highest yields were obtained when [1]apple pomace was dried and ground to obtain an apple flour to be used as raw material, [2] citric or nitric acids were used and [3] when the citric acid concentration was $6.2 \mathrm{~g} / 100 \mathrm{ml}$ and the time of reaction was 153 minutes. The apple variety in itself was not significant in pectin yield. The degree of esterification $(D E=68.84 \%)$ of the product obtained, as well as its physical looks, show the success of pectin extraction.
\end{abstract}

Key words: Apple pomace, pectin, agricultural wastes, yield, extraction, Response Surface Methodology (RSM)

\section{INTRODUCTION}

Citrus albedo and apple pomace are rich in pectic substances and important raw materials for pectin production all around the world (Fox, 1984). There is only one factory in Brazil producing citrus pectin, in Limeira, State of São Paulo (Cpkelco, 2002) but none producing apple pectin. The Brazilian apple production, however, quickly spread in the Southern States of the Country in the 70's (Wosiacki, 2001) and in the 2002 / 2003 crop, the apple production was estimated at 980,000 tons, with approximately 180,000 tons for industrial processing. Nowadays, about 50,000 tons of wet pomace are produced in Brazil. A possibility for large enterprises is the drying of this wet raw material aiming at the production of apple pectin (Endress, 2000). Apple pomace is produced as a by-product of the juice factories and currently it is either used for animal feeding or is disposed of as an industrial waste. If apple pomace could be used the production of pectin, around 2000 tons of pectin could be produced each year.

Pectin is a family of complex variable polysaccharides extracted from the primary cell wall of higher plants. Chemically, pectin consists of linear polymers of $\mathrm{D}-\alpha-(1 \rightarrow 4)$ anhydrogalacturonic acid. Part of the carboxyl groups of the anhydro-galacturonic acid is esterified with methanol (Wosiacki, 1977). Vauquelin stated its chemical nature in 1790 and Braconnot showed the characteristic of geleification and gave it the name pectin (Berk, 1976). Pectin is widely used as a functional ingredient in the food industry due to its ability to form aqueous gels and has been used in jams and jellies, fruit preparations, fruit drink

\footnotetext{
${ }^{*}$ Author for correspondence
} 
concentrates, fruit juice, desserts and fermented dairy products. Commercial pectin is currently classified according to the degree of esterification (DE). There are three classifications of pectin: HM (high ester); LMC (low ester conventional) and LMA (low ester amidated) according to CPKelco (2002).

Pectin in apple pomace is mainly present in the form of protopectin, an acid soluble polysaccharide. The condition for the acid extraction of pectin is somewhat obscure in the literature and it is very difficult to visit processing units. There are complicated procedures in its study (Thibault et alli, 1991), although pectin has been under investigation since the start of $20^{\text {th }}$ century (Kertesz, 1951). Some experimental research should be done in order to clarify this important industrial step so as to utilize apple pomace as the main raw material for the extraction of pectin. The objectives of this work were to extract pectin from apple pomace on a laboratory scale and to characterize it in order to observe the influence of some factors on the yield of pectin.

\section{MATERIALS AND METHODS}

\section{Materials}

Samples from nine different apple varieties (Belgolden, Catarina, Eva, Fred Hough, Fuji, Gala, MRC, Rainha and Sansa) were used as raw material in this work. They were processed together in order to obtain an apple pomace pool, according to industrial procedure. In the laboratory, all the fruits were first washed and ground in an electric grater. The crushed pulp was then pressed and the apple pomace dried, initially at room temperature and then at $50^{\circ} \mathrm{C}$, to a constant weight with air circulation. This dry apple pomace pool was then crushed and mixed and the product was called apple flour and it was used as the raw material for all the assays made concerning pectin extraction and characterization.

Three apple flour varieties were selected (Belgolden, Catarina and Eva) in order to establish the influence of apple variety on the yield of pectin extraction and the results were compared with a pomace pool of all the apple varieties.

\section{Pectin extraction}

Five replicates for each assay were made. Pectin was extracted under reflux in a condensation system at $97^{\circ} \mathrm{C}$ for $30 \mathrm{~min}$ (solute/solvent 1:50), using water acidified with citric acid to $\mathrm{pH} 2.5$, using apple flour (pool) as raw material. Next, the pool was classified with four metallic sieves $(1,18$ $\mathrm{mm}, 600 \mu \mathrm{m}, 250 \mu \mathrm{m}$ and $106 \mu \mathrm{m})$ in a shaker device in order to separate them in five portions with different particle sizes. Three batches, as well as crude dried pomace without crushing were used to observe the effect of particle size on pectin yield. The extraction of pectin was performed with apple pomace from selected varieties under equal conditions.

Pectin extraction was also performed under reflux at $97^{\circ} \mathrm{C}$ for $30 \mathrm{~min}$ (solute/solvent 1:50), using water acidified with different acids, to investigate the effect of each kind at $\mathrm{pH} 2.5$ and to ratify the use of citric acid. In this assay, the raw material selected was the apple flour pool with particles between 250 and $105 \mu \mathrm{m}$. The selected acids utilized for extraction were citric, phosphoric, hydrochloric, nitric, malic, tartaric and sulfuric acids.

Pectins extracted in each trial were all mixed and the degree of esterification was analyzed (Gee et al., 1959). The analysis of variance (ANOVA) was used to define the optimum conditions concerning the acid used for pectin extraction, the apple variety and the size of particles of the apple pomace.

\section{Isolation of pectin}

Hot acid extract was pressed in a cheese cloth bag and the concentrated "juice" was cooled to $4^{\circ} \mathrm{C}$. The apple pectin was precipitated by alcohol-juice treatment 2:1 (v/v). The mixture of solvent and precipitate was stirred for ten minutes and then left to rest for one hour in order to allow pectin flotation. With this procedure the pectic substances remain at the surface of the alcohol/water mixture and thus it is easier to remove them in a quantitative way.

The floating pectin was filtered through cheesecloth, rinsed with $95^{\circ} \mathrm{GL}$ alcohol and then pressed. The pressed pectin was dried to constant weight at $55{ }^{\circ} \mathrm{C}$, cooled in a dessicator and the yield calculated on a dry weight basis (inicial weight of sample). The hard pectin cake was broken up, ground and sieved in order to obtain powdered pectin.

\section{Experimental design}

Response surface methodology was used to optimize pectin extraction with respect to time and 
acid concentration; the temperature was maintained constant at $97^{\circ} \mathrm{C}$, the boiling point of water in the laboratory. A five-level two-factor fractional design was adopted. The response surface model equation is (1):

$$
\begin{gathered}
\mathrm{Y}=\mathrm{b}_{\mathrm{o}}+\mathrm{b}_{1} \mathrm{x}_{1}+\mathrm{b}_{2} \mathrm{x}_{2}+\mathrm{b}_{11} \mathrm{x}_{1}^{2}+ \\
\mathrm{b}_{22} \mathrm{x}_{2}^{2}+\mathrm{b}_{12} \mathrm{x}_{1} \mathrm{x}_{2}(1)
\end{gathered}
$$

where $\mathrm{Y}$ is the response variable of pectin yield $(\%) ; \mathrm{b}_{1}$ and $b_{2}$ are regression coefficients for linear effects; $b_{12}$ is the regression coefficient for interaction effects; $b_{11}$ and $b_{22}$ are regression coefficients for quadratic effects, and $\mathrm{x}_{1}$ and $\mathrm{x}_{2}$ are coded experimental levels of the variables. Statistica for Windows was used to match the quadratic equation with the experimental data.

\section{Optimization}

The apple flour suspensions were heated at $97^{\circ} \mathrm{C}$ under reflux with a glass condensation device. The factors studied were citric acid concentration $(\mathrm{CAC}=0.05-9.95 \mathrm{~g} \%)$ and heating time $(\mathrm{HT}=10$ $210 \mathrm{~min})$. Citric acid was always added to the flasks when the system reached the boiling point. The experiment was conducted using a five-level two-factor composite design with three assays at the central point. In order to maximize the pectin extraction, coded and real levels, based on previous experiments, were selected. Both factor variations can be seen in Table 1 . The test runs were performed in a random order according to a Statistic for Windows tool.

Table 1 - Coded and real levels of variables

\begin{tabular}{c|c|c|c|c|c}
\hline \multirow{2}{*}{ Variable } & \multicolumn{5}{c}{ Coded level of variables } \\
\cline { 2 - 6 } & $-\sqrt{\mathbf{2}}$ & $\mathbf{- 1}$ & $\mathbf{0}$ & $\mathbf{+ 1}$ & $+\sqrt{\mathbf{2}}$ \\
\hline $\begin{array}{c}\mathrm{X}_{1}: \\
\text { citric acid, } \mathrm{g} / 100 \mathrm{ml} \\
\begin{array}{c}\mathrm{X}_{2}: \\
\text { time, min. }\end{array}\end{array}$ & 0.05 & 1.5 & 5 & 8.5 & 9.95 \\
\hline
\end{tabular}

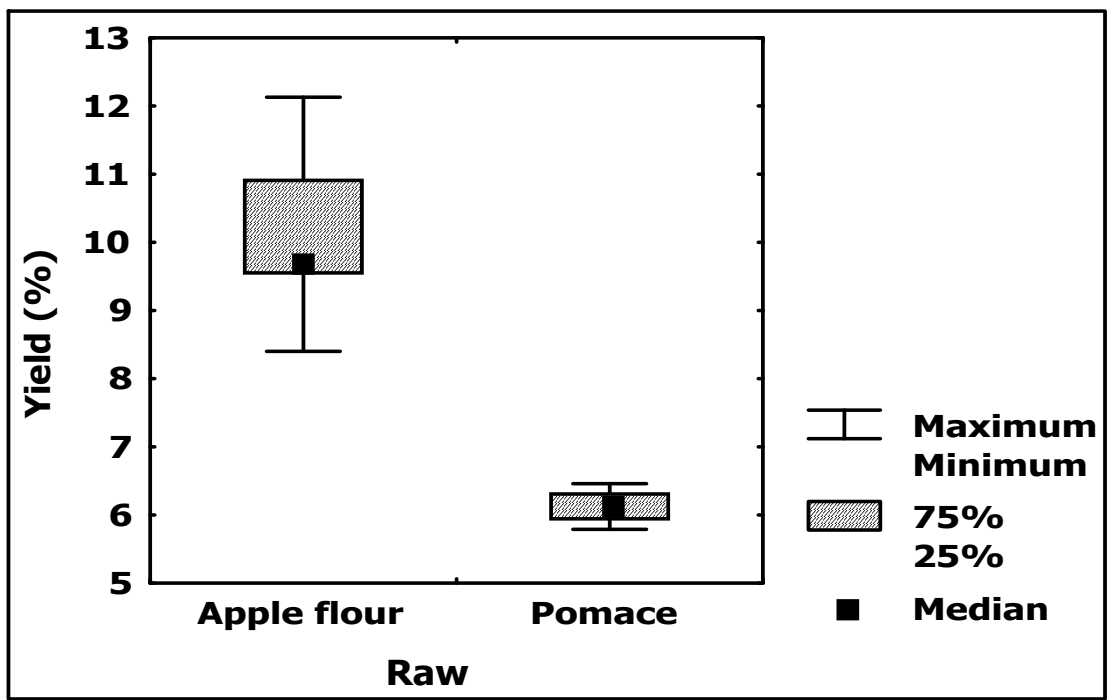

Figure 1 - Effect of particle size on the yield of extraction using apple flour and apple pomace as a pectin source. 


\section{RESULTS AND DISCUSSION}

\section{Effect of the size of the particles}

According to the results (Fig. 1), the pectin yield was significantly higher with the use of flour as raw material $(9.73 \%)$; when the extraction was made from the pomace the yield was $6.13 \%$. There are several explanations for this fact, but protopectin is more available in small particles than in large ones.

Three apple flour fractions were collected during the study of the particle size and used to confirm these results.

The flour fractions with particles larger than 600 $\mu \mathrm{m}$ showed lower pectin yield while when smaller particles were used the yield was higher (Fig. 2).

\section{Effect of apple variety}

Although some varieties do have a high concentration of soluble pectin in the apple juice, the pectin extracted from the pomace did not show a pronounced variation, although there was a statistical difference amongst the varieties. The blend of varieties results in a raw material more similar to industrial raw pomace constituted of various apple varieties in indeterminate proportions and several maturation stages (Fig. 3).

\section{Effect of different acids on pectin extraction}

Several acids can be utilized for the extraction of pectin. According to Kertesz (1951), the acids used for pectin extraction were the tartaric, malic, citric, lactic, acetic and phosphoric acids but there was a tendency to use the cheaper mineral acids, such as sulfuric, hydrochloric and nitric acids. Articles published recently recommend the use of hydrochloric (Kalapathy and Proctor, 2001; Hwang et al., 1998; Dinu, 2001) and nitric acids (Pagán et al., 2001).

According to Fig. 4, the lowest yields were obtained when phosphoric and malic acids were used. Although nitric acid showed the highest yield, the variation was very large. Citric acid had the highest average value $(13.75 \%)$ and it is better than the other acid from an economic as well as from an environmental point of view. The analysis of variance indicated statistical significance in the yield.

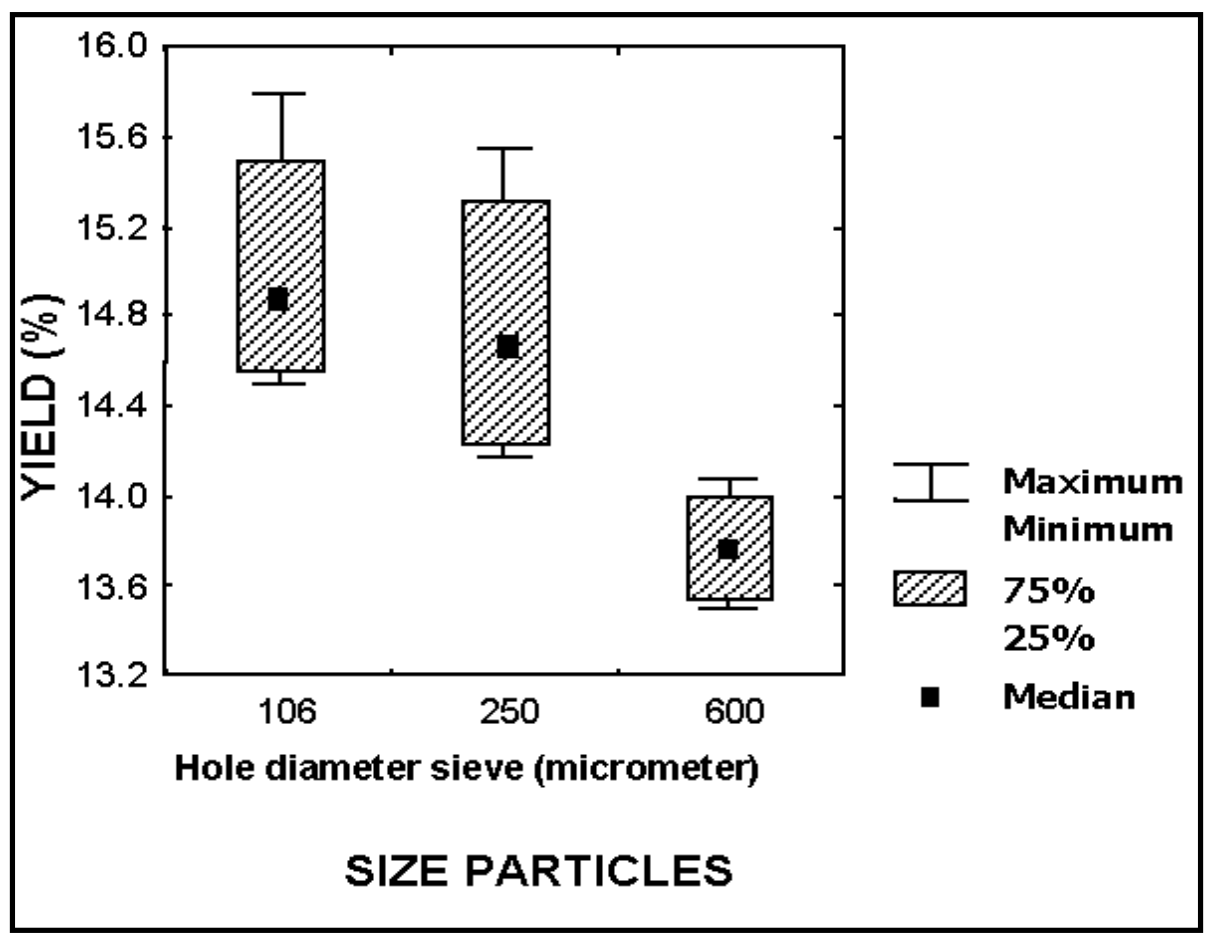

Figure 2 - Effect of particle size on the pectin extraction yield. 


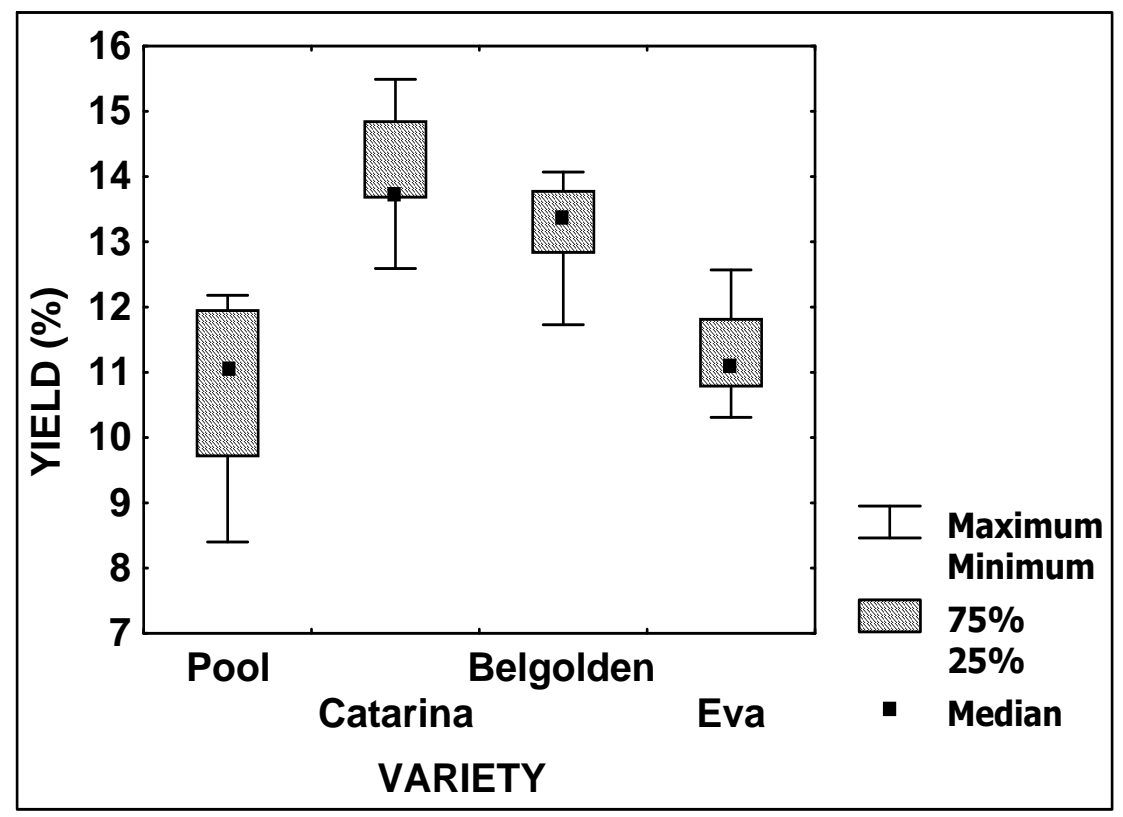

Figure 3 - Effect of apple variety on the pectin extraction yield.

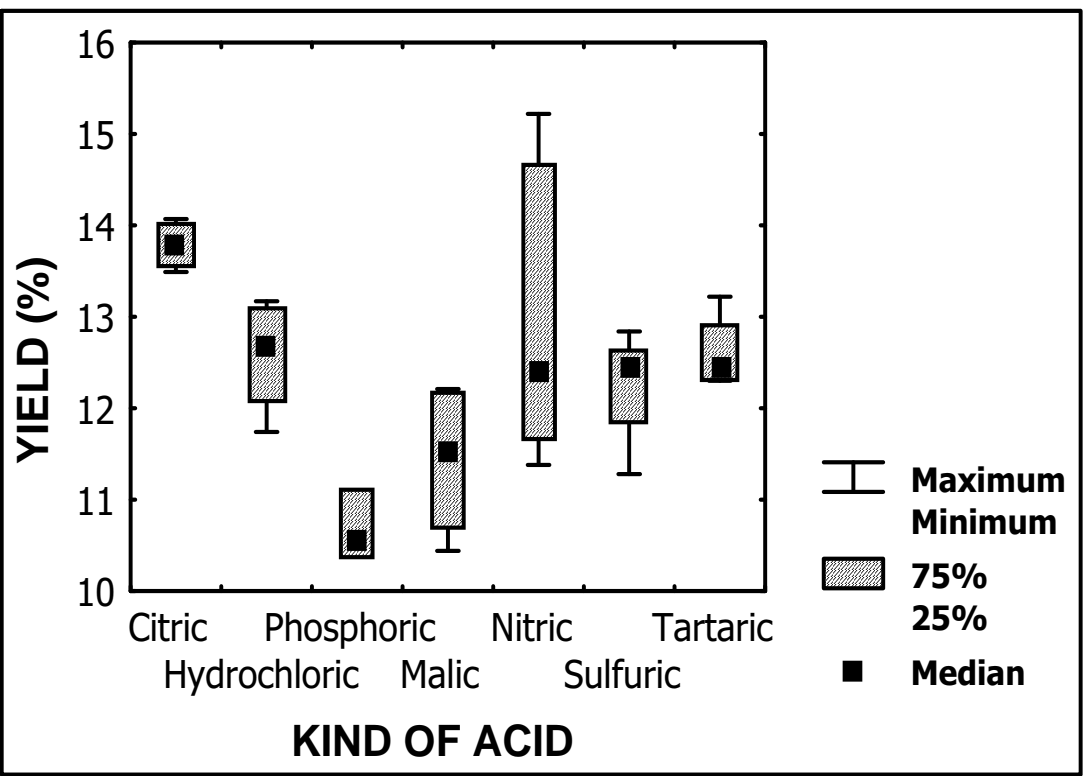

Figure 4 - Effect of the kind of acid on the pectin extraction yield.

\section{Optimization of yield}

Table 2 shows the experimental design and its results. The average results of the central coordinates were $20 \pm 0.86$, which represented a low variation coefficient of $4.8 \%$.

The regression analysis showed that $93.55 \%$ of the variations was explained by the model. The predictive equation explains a surface with a maximum point with coordinates $\mathrm{X} 1=152.85$ minutes and $\mathrm{X} 2=6.2 \mathrm{~g} \%$ of citric acid with a theoretical maximum yield of $17.82 \mathrm{~g} \%$ of pectin on a dry basis (Equation 2).

$$
\begin{gathered}
\mathrm{z}=19.9957+0.8819 \mathrm{x}-2.4457 \mathrm{x}^{2}+1.3865 \mathrm{y}- \\
1.5613 \mathrm{y}^{2}+1.4215 \mathrm{xy}+0
\end{gathered}
$$

The results indicated that the yield of pectin was dependent on the linear terms, on the quadratic terms and also on the interactions of both variables. Table 3 illustrates the coefficients of the regression model for the determination of pectin. 
Both linear and quadratic effects showed significance in accordance with the analysis of variance. The experimental design indicated the formation of a surface where the pectin extraction yield was optimum, between 18 and 20\%. Fig. 5 illustrates this surface in three dimensions, clearly showing a critical point of high yield with an equation statistically significant according to ANOVA, since $F_{\text {cal }}(6.005665)>F_{\text {crt }}$ (4.256492).

The degree of esterification of the apple pool pectin was $68.84 \%$ on average, as could be expected from mature apples.

Table 2 - Experimental design and pectin extraction yield.

\begin{tabular}{|c|c|c|c|c|c|}
\hline \multirow{3}{*}{ Run } & \multicolumn{4}{|c|}{ Level } & \multirow{3}{*}{$\begin{array}{l}\text { Yield } \\
\text { (g\%) }\end{array}$} \\
\hline & \multicolumn{2}{|c|}{ Coded } & \multicolumn{2}{|c|}{ Real } & \\
\hline & Citric acid (g\%) & $\overline{\text { Time (min.) }}$ & Citric acid (g\%) & Time (min.) & \\
\hline 1 & -1 & -1 & 1.5 & 39.3 & 15.59 \\
\hline 2 & -1 & 1 & 1.5 & 180.7 & 15.88 \\
\hline 3 & 1 & -1 & 8.5 & 39.3 & 13.30 \\
\hline 4 & 1 & 1 & 8.5 & 180.7 & 19.27 \\
\hline 5 & $-\sqrt{2}$ & 0 & 0.05 & 110 & 12.98 \\
\hline 6 & $\sqrt{ } 2$ & 0 & 9.95 & 110 & 17.18 \\
\hline 7 & 0 & $-\sqrt{2}$ & 5 & 10 & 15.14 \\
\hline 8 & 0 & $\sqrt{2}$ & 5 & 210 & 18.56 \\
\hline 9 & 0 & 0 & 5 & 110 & 20.92 \\
\hline 10 & 0 & 0 & 5 & 110 & 19.23 \\
\hline 11 & 0 & 0 & 5 & 110 & 19.83 \\
\hline
\end{tabular}

Table 3 - Analysis of variance of regression model of experimental design.

\begin{tabular}{l|c|c|c|c|c|c}
\hline \multicolumn{1}{c|}{ Factor } & $\begin{array}{c}\text { Regression } \\
\text { Coefficient }\end{array}$ & $\begin{array}{c}\text { Standard } \\
\text { Error }\end{array}$ & T(s) & $\mathbf{P}$ & $\begin{array}{c}\mathbf{- 9 5 \%} \\
\text { Cnf.Limt }\end{array}$ & $\begin{array}{c}+\mathbf{9 5 \%} \\
\text { Cnf.Limt }\end{array}$ \\
\hline Mean/ Interaction & 19.9956 & 0.5580 & 35.8305 & $3.19 \mathrm{E}-07$ & 18.5611 & 21.4302 \\
(1) Citric acid (L) & 1.7639 & 0.6835 & 2.5805 & 0.0493 & 0.0068 & 3.5209 \\
(2) Citric acid (Q) & -4.8913 & 0.8136 & -6.0114 & 0.0018 & -6.9829 & -2.7997 \\
(3) Time (L) & 2.7730 & 0.6835 & 4.0568 & 0.0097 & 1.0159 & 4.5301 \\
(4)Time (Q) & -3.1225 & 0.8136 & -3.8376 & 0.0121 & -5.2142 & -1.0309 \\
1L*2L & 2.8430 & 0.9665 & 2.9412 & 0.0322 & 0.3583 & 5.3277 \\
\hline
\end{tabular}

$\mathrm{L}=$ linear effects

$\mathrm{Q}=$ quadratic effects

\section{CONCLUSIONS}

When the effects of particle size were studied it was found that the highest average yields of around $14 \%$ were obtained when the particle was larger than $106 \mu \mathrm{m}$ and smaller than $250 \mu \mathrm{m}$.

Extraction of pectin using pomace as raw material produced a lower pectin yield than when apple flour was used. This result indicated that it was necessary to produce apple flour as an intermediary step in the acid extraction of pectin from pomace. Pectin extraction from different varieties of apple pomace did not show any significant effect on pectin yield as compared with a pool of apple samples. Citric acid and nitric acid showed the highest yield among the organic and mineral acids tested.

The coordinates of the stationary point were found to correspond to $6.2 \mathrm{~g} / 100 \mathrm{ml}$ of citric acid with a reaction time around $150 \mathrm{~min}$. The apple pool pectin showed a degree of esterification of approximately $68.84 \%$. 


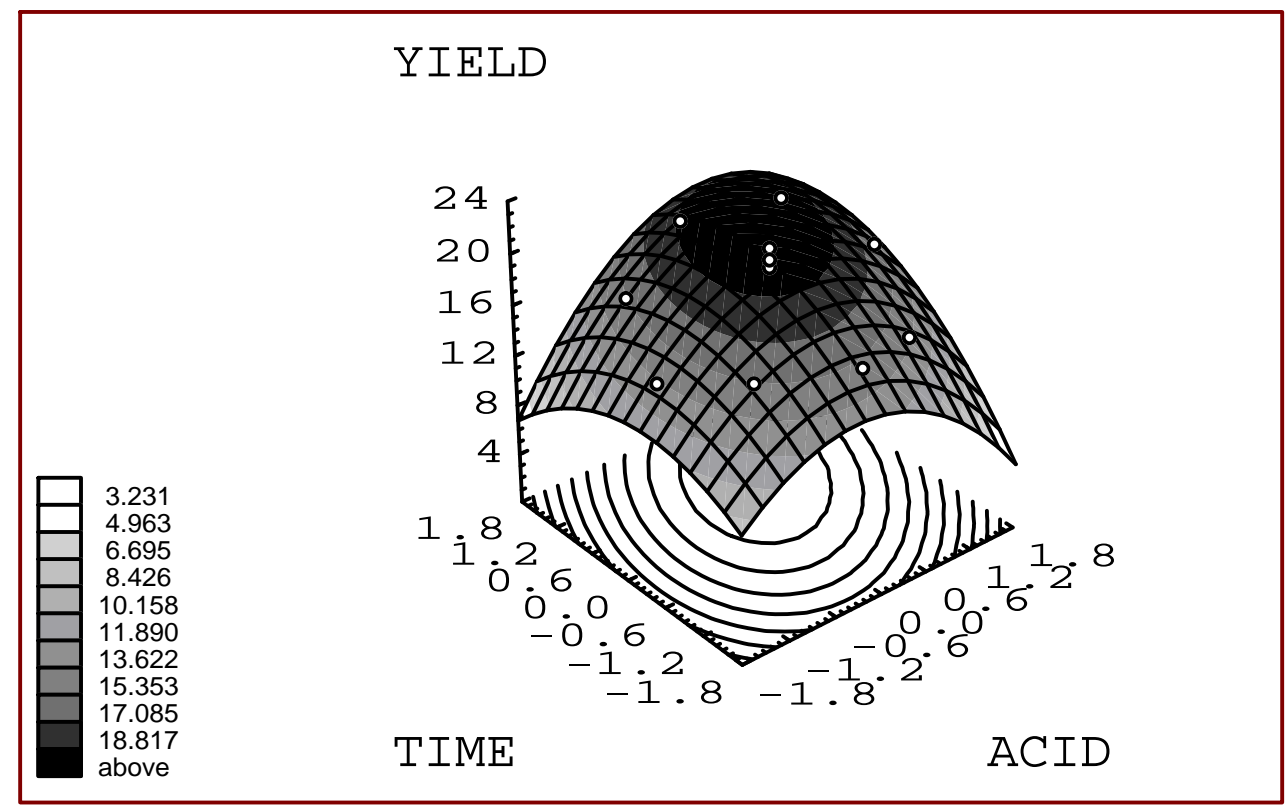

Figure 5 - 3-D dimension response surface of experimental design (five-level two-factor composite) on the pectin extraction yield.

\section{RESUMO}

No aproveitamento de resíduos das indústrias processadoras de maçã, em expansão no Brasil, a pectina alimentícia surge como importante subproduto. Os objetivos deste trabalho foram os seguintes: extração e caracterização da pectina de bagaço de maçã em bancada, em que as condições para maior rendimento de obtenção em relação ao tipo de ácido, ao tamanho das partículas e à variedade de maçã foram estabelecidas. Objetivouse também a otimização da produção, levando-se em conta o tempo e a concentração do ácido cítrico. Foram considerados métodos de extração mais eficientes quanto ao rendimento: [1] acidificação com ácido cítrico ou ácido nítrico, [2] cominuição do bagaço, usando a farinha como matéria-prima, com partículas retidas no tamis de $106 \mu \mathrm{m}$, [3] concentração de ácido de 6,2 g\% e tempo de extração de 153 minutos. A variedade da maçã não interferiu significativamente no rendimento. A alta metoxilação ( $\mathrm{DE}=68,84 \%)$ das pectinas produzidas em bancada confirma o grau de maturidade das matérias-primas usadas nos experimentos.

\section{ACKNOWLEDGEMENTS}

The experimental work was done at the Ponta Grossa State University and the authors are deeply grateful to the staff of GTM - Apple Research Team (Departamento de Engenharia de Alimentos) for the technical and the scientific support. The authors are also grateful to $\mathrm{CNPq}$ for scholarship and to ABPM, to CEFET/PR-U-PG, to AGRICOLA FRAIBURGO, to CPKelco and to EPAGRI for technical cooperation.

\section{REFERENCES}

Berk, Z. (1976), Braverman's introduction to biochemistry of foods. Amsterdam: Elsevier, $375 \mathrm{pp}$.

Chang, K. C.; Dhurandhar, X. and You, M. A. (1994), Cultivar/Location and processing methods affect yield and quality of sunflower pectin. Journal of Food Science, 59, 602-605.

CPKelco (2002), Fluxograma de produção de pectina cítrica,Folder, Limeira, São Paulo.

Dinu, D. (2001), Extraction and characterization of pectins from wheat bran. Roumanian Biotechnology Letter, 6, 37-43.

Endress, H. U. (2000), High quality resulting from product integrated environment protection - PIUS. Fruit Processing, 10, 273-276. 
Fox, G. (1984), Zur Wirtschaftlichkeit der Trocknung von Apfeltrester. Confructa Studien, 28, 174-182.

Gee, M.; Reeve, R. M. and Mcready, R. M. (1959), Reaction of hydroxylamine with pectinic acids. Chemical studies and histochemical estimation of the degree of esterification of pectic substances in fruit. Journal of Agricultural and Food Chemistry, 07, 34-38.

Hwang, Jae-Kwan; Kim, Chul-Jin and Kim, Chong-Tai (1998), Extrusion of Apple Pomace Facilitates Pectin Extraction. Journal of Food Science, 63, 841-844.

Kalapathy, U. and Proctor, A. (2001), Effect of acid extraction and alchool precipitation conditions on the yield and purity of soy hull pectin. Food Chemistry, 72, 393-396.

Kertesz, Z. I. (1951), The pectic substances. New York: Interscience. pp. 438.

Pagán, J.; Ibarz, A.; Llorca M.; Pagán A. and BarbosaCánovas G. V. (2001), Extraction and characterization of pectin from stored peach pomace. Food Research International, 34, 605-612.

Thibault, J. F.; Saulnier, L.; Axelos, M. A. V. and Renard, C. M. G. C. (1991), Difficultés expérimentales de l'étude des macromolecules pectiques. Bulletin Societé Botanique Française, 138, 319-337.

Wosiacki, G. (1977), Enzimas pectinolíticas de Fusarium oxysporum Schlecht ex. Fr. Isolado de frutos de café, Thesis, Universidade Estadual de Campinas, São Paulo, Brasil.

Wosiacki, G. and Nogueira, A. (2001), Apple varieties growing in subtropical areas. The situation in Paraná State. Fruit Processing, 11, 177-182.

Received: May 14, 2003; Revised: December 08, 2003; Accepted: December 13, 2004. 